\title{
ACE Inhibitory Activity and Functional Group Analysis of Solvent- Partitioned Fractions of Eleusine indica
}

\author{
Jade Celon Cometa, Liahona Faith Roldan Mancol, Anthony Nalzaro Yen, Joanne Katherine \\ Talens Manlusoc*
}

Adamson University - College of Pharmacy, 900 San Marcelino St. Ermita Manila 1000 Philippines

\begin{abstract}
Eleusine indica Linn. Gaerth or Indian goose grass has been widely used as an alternative natural anti-hypertensive agent. However, the rationale behind this mechanism is still unknown. The purpose of this study is to confirm the presence of functional groups that may be responsible for its ACE inhibitory activity and its possible synergism. Each solvent-portioned fraction was analyzed by FTIR, individual ACE inhibitory activity, and combination of fractions. FTIR results of solventpartitioned fractions revealed that $\mathrm{O}-\mathrm{H}$ and $\mathrm{C}-\mathrm{H}$ stretches were present in all fractions. In addition to this, $\mathrm{C}-\mathrm{O}$ and $\mathrm{C}=\mathrm{O}$ groups were also present in all fractions except in ethyl acetate. $\mathrm{S}=\mathrm{O}$ groups were also present in chloroform, ethyl acetate, and n-butanol fractions. Other function groups such as $\mathrm{N}-\mathrm{O}$ and $\mathrm{C}=\mathrm{C}$ groups were present in ethyl acetate and n-butanol fractions, respectively. The highest \% inhibition obtained among the individual fraction is n-butanol at $96.031 \% \pm 0.004$ at $500 \mathrm{ug} / \mathrm{ml}$. The lowest \% inhibition obtained among the individual fraction is chloroform at $32.544 \% \pm 0.011$ at $500 \mathrm{ug} / \mathrm{ml}$. The highest \% inhibition among the combined fractions is ethyl acetate:butanol at $95.727 \% \pm 20.847$, while the lowest \% inhibition in combination is hexane:chloroform at $89.626 \% \pm 19.577$. The fraction with the lowest $\mathrm{IC}_{50}$ is hexane at 15.357 , while the highest $\mathrm{IC}_{50}$ is chloroform at $168.207 \mathrm{ug} / \mathrm{ml}$. Functional group present may be associated with the antihypertensive activity of the $E$. indica extracts. The more polar solvent-partitioned fractions of E. indica has a higher ACE inhibitory activity compared to its less polar solventpartitioned fractions. The higher ACE inhibitory activity may be associated with the secondary metabolites present in the more polar fractions. There is also possible synergism present in the combined solvent-partitioned fractions as their \% inhibition is higher than their individual effects.
\end{abstract}

Keywords: Eleusine indica; paragis; ace inhibition; FTIR; ace kit-wst

*corresponding author

Email: joanne.manlusoc@adamson.edu.ph

\section{INTRODUCTION}

Eleusine indica or commonly known in the Philippines as paragis, is a terrestrial plant with a wide distribution across the world including Asia, Africa, North America, and parts of Europe due to its wide tolerance to various environmental conditions. (Cha, et al., 2014). Aside from this, E. indica is a native plant in tropical and subtropical regions like the Philippines. Traditionally, its decoction from the leaves are used to treat asthma, muscle pains, febrifuge, diarrhea, and dysentery. In addition, $E$. indica is used to treat bladder disorders, convulsions and childbirth aid in other countries. The whole plant is usually used as a diuretic, laxative, and depurgative making it useful for the treatment of influenza, oliguria, and hypertension (Ettebong et al., 2012).

Hypertension is a major risk factor for cardiovascular diseases that commonly affects adults. Since high blood pressure is usually asymptomatic in its initial stages, it has been labelled as a silent killer. It can cause diseases such as heart failure, kidney failure, and stroke. (Amin et al, 2013). According to the World Health Organization (WHO) (2017), the rampant increase of hypertension cases is associated with population growth, aging and behavioral risk factors. The Renin-AngiotensinAldosterone-System (RAAS), a powerful arterial blood pressure regulator, has become a focus on the hunt for targets in the elimination of hypertension. (Bangalore et al., 2016). A component of the RAAS is the AngiotensinConverting Enzyme (ACE) which in high levels leads to increased concentration of angiotensin II causing to hypertension.

In the study of Hernandez and Tutor (2018), hexane and ethyl acetate sequential fractions of $E$. indica showed lower ACE inhibitory activity compared to the crude methanolic extract. The researchers attribute the result to a possible synergism, an activity in which activity is lost in purified fractions.

In this study, the researchers confirm the presence of functional groups that may be responsible for its ACE inhibitory activity. 


\section{METHODS}

\section{Chemicals}

The ACE kit-WST by Dojindo Molecular Technologies, Inc. was purchased from Integrated Biolabs, Taiwan.

\section{Plant Sample Preparation}

$E$. indica was collected from the wide grasslands of San Fernando, Romblon, Philippines as the grass is abundant and grows all year round. The plant samples were collected in October 2018. The plant samples were cleaned with distilled water and were air-dried in shade for 3 days. It was grinded with a Wiley-mill grinder and stored in a wide mouthed amber bottle. The samples were identified and authenticated by Philippine Bureau of Plant Industry (BPI) and a voucher specimen was made.

\section{Crude Extraction}

The extraction was adapted from the study of Hernandez and Tutor (2018) with a slight modification. Dried powdered sample of $E$. indica was soaked in methanol for 3 days. The sample was collected using a percolator and was evaporated in a digital water bath at $40^{\circ} \mathrm{C}$. The collected methanolic extract was oven-dried and weighed. The \% yield was calculated using the formula:

$\%$ Yield $=($ weight of crude extract/total weight of sample $) \times 100$

\section{Solvent Partition}

The solvent partition method was adapted from the methods of Kupchan (2016) with slight modifications by adding chloroform into the process. Five $g$ of the crude methanolic extract was partitioned using hexane, chloroform, ethyl acetate, and n-butanol to obtain their fractions. The fractions obtained were evaporated in a digital hot bath at $50^{\circ} \mathrm{C}$. and were dried in an oven at $40^{\circ} \mathrm{C}$ and weighed.

\section{Fourier Transform Infrared (FTIR) Analysis}

The spectra measurement of the crude methanolic extract and the fractions collected was performed using the PerkinElmer Spectrum Two FT-IR. A pinch amount of the dried samples was placed in the universal attenuated total reflectance (ATR) (Rohman \& Che, 2012).

\section{ACE Inhibitory Activity Determination}

ACE inhibition assay kit was used to determine the angiotensin converting enzyme inhibitory activity from the obtained crude methanolic extract, solventpartitioned fractions of hexane, chloroform, ethyl acetate, and n-butanol, and its chosen combination.

The working solution was prepared as specified in the manual included in the kit. A solution containing Enzyme $\mathrm{B}$ was prepared by dissolving the solution with $2 \mathrm{ml}$ of deionized water. Then, $1.5 \mathrm{ml}$ of the solution was added to Enzyme A to prepare the Enzyme sample. An indicator working solution was also prepared by dissolving a solution containing Enzyme $\mathrm{C}$ and coenzyme with 3 $\mathrm{ml}$ each of deionized water. Afterwards, $2.8 \mathrm{~mL}$ of the solution containing Enzyme $\mathrm{C}$ was added to $2.8 \mathrm{ml}$ of coenzyme solution for the preparation of the indicator working solution. The sample solution was prepared into several portions by diluting it with deionized water by two-fold dilution. Starting concentration was $500 \mu \mathrm{g} / \mathrm{mL}$ of plant extract.

Twenty $\mu$ of sample solution was placed in a well and a separate two $20 \mu \mathrm{l}$ of deionized water for blank 1 and blank 2 . Twenty $\mu$ of the substrate buffer was placed on all wells. Twenty $\mu \mathrm{l}$ of deionized water was added to the well of blank 2. Subsequently, $20 \mu$ l of enzyme solution was added to each sample well and blank 1 well. The plate was incubated at $37^{\circ} \mathrm{C}$ for 1 hour. Afterwards, $200 \mu \mathrm{l}$ of indicator working solution was added to all wells. In the final step, the solution was incubated at room temperature for 10 minutes before the absorbance was read at $450 \mathrm{~nm}$ using a microplate reader (Dojindo Laboratories, 2016).

ACE inhibitory activity was calculated by the following equation:

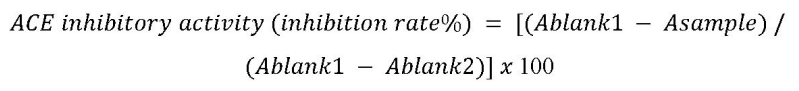

$\mathrm{IC}_{\mathbf{5 0}}$

$\mathrm{IC}_{50}^{50}$ was determined using Quest $\mathrm{Graph}^{\mathrm{TM}} \mathrm{IC}_{50}$ Calculator.

The formula used is as follows:

$$
Y=\operatorname{Min}+\frac{\operatorname{Max}-\operatorname{Min}}{1+\left(\frac{X}{I_{50}}\right)^{\text {Hill coefficient }}}
$$

\section{RESULTS AND DISCUSSION}

\section{FTIR}

The FTIR analysis was performed to identify the functional groups present in the crude methanolic extract and various solvent-partitioned fractions of $E$. indica. The FTIR spectroscopic analysis showed various functional groups present in the plant and exists both or copiously on almost all solvent-partitioned fractions.

The crude methanolic extract (Figure 1) FTIR results revealed that the O-H $\left(3200-2700 \mathrm{~cm}^{-1}\right.$ and $1420-1330$ $\left.\mathrm{cm}^{-1}\right)$, and $\mathrm{C}-\mathrm{H}\left(3000-2840 \mathrm{~cm}^{-1}\right.$ and $\left.700 \pm 20 \mathrm{~cm}^{-1}\right)$ groups have been detected. In addition, $\mathrm{C}-\mathrm{O}$ and (1210$\left.1163 \mathrm{~cm}^{-1}\right)$ and $\mathrm{C}=\mathrm{O}\left(1710-1680 \mathrm{~cm}^{-1}\right)$ groups were also detected. 
Peak Table Spectrum

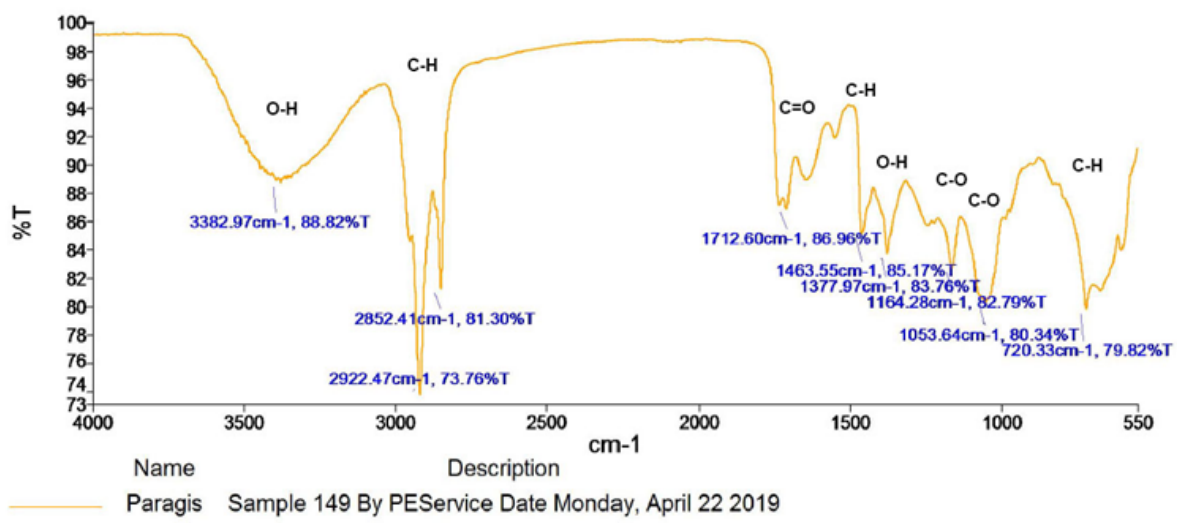

Figure 1. FTIR spectra of crude methanolic extract

Peak Table Spectrum

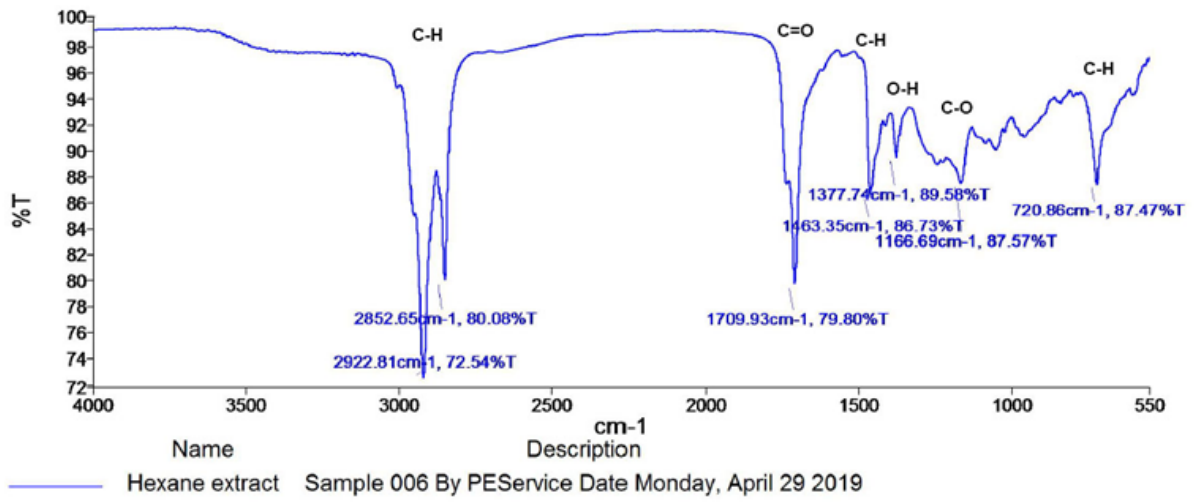

Figure 2. FTIR spectra of hexane-partitioned fraction

The hexane-partitioned fraction (Figure 2) FTIR results revealed that the O-H (3200-2700 $\mathrm{cm}^{-1}$ and 1420-1330 $\left.\mathrm{cm}^{-1}\right)$, and $\mathrm{C}-\mathrm{H}\left(3000-2840 \mathrm{~cm}^{-1}\right.$ and $\left.700 \mathrm{~cm}^{-1}\right)$ groups have been detected. In addition, $\mathrm{C}-\mathrm{O}$ and $\left(1210-1163 \mathrm{~cm}^{-}\right.$ $\left.{ }^{1}\right)$ and $\mathrm{C}=\mathrm{O}\left(1710-1680 \mathrm{~cm}^{-1}\right)$ groups were also detected.

The chloroform-partitioned fraction (Figure 3) FTIR results revealed that the $\mathrm{O}-\mathrm{H}\left(3200-2700 \mathrm{~cm}^{-1}\right.$ and $1420-$ $\left.1330 \mathrm{~cm}^{-1}\right)$, and $\mathrm{C}-\mathrm{H}\left(3000-2840 \mathrm{~cm}^{-1}\right.$ and $\left.700 \mathrm{~cm}^{-1}\right)$ groups have been detected. In addition, C-O and (1210$\left.1163 \mathrm{~cm}^{-1}\right)$ and $\mathrm{C}=\mathrm{O}\left(1710-1680 \mathrm{~cm}^{-1}\right)$ groups, and notably, an $\mathrm{S}=\mathrm{O}$ functional group, were all present.

The ethyl acetate-partitioned fraction (Figure 4) FTIR results revealed that the $\mathrm{O}-\mathrm{H}\left(3200-2700 \mathrm{~cm}^{-1}\right.$ and $1420-$ $\left.1330 \mathrm{~cm}^{-1}\right)$, and C-H (3000-2840 $\mathrm{cm}^{-1}$ and $\left.700 \mathrm{~cm}^{-1}\right)$ groups have been detected. Notably, $\mathrm{S}=\mathrm{O}(1372-1335$ $\mathrm{cm}^{-1}$ and 1070-1030 $\left.\mathrm{cm}^{-1}\right)$ and N-O (1650-1580 $\left.\mathrm{cm}^{-1}\right)$ functional groups were detected.

The n-butanol-partitioned fraction (Figure 5) FTIR results revealed that the $\mathrm{O}-\mathrm{H}\left(3200-2700 \mathrm{~cm}^{-1}\right.$ and $\left.1420-1330 \mathrm{~cm}^{-1}\right)$, and $\mathrm{C}-\mathrm{H}\left(3000-2840 \mathrm{~cm}^{-1}\right.$ and 700 $\mathrm{cm}^{-1}$ ) groups were detected. In addition, C-O and (1210$\left.1163 \mathrm{~cm}^{-1}\right)$ and $\mathrm{C}=\mathrm{O}\left(1710-1680 \mathrm{~cm}^{-1}\right)$ groups were also detected. Notably, $\mathrm{S}=\mathrm{O}\left(1372-1335 \mathrm{~cm}^{-1}\right.$ and $1070-1030$ $\left.\mathrm{cm}^{-1}\right)$ and $\mathrm{C}=\mathrm{C}\left(1678-1668 \mathrm{~cm}^{-1}\right)$ group were detected as well.

The overlaid spectra (Figure 6) showed all individual solvent-portioned fractions to have the O-H (3200-2700 $\mathrm{cm}^{-1}$ and $\left.1420-1330 \mathrm{~cm}^{-1}\right)$, and C-H (3000-2840 $\mathrm{cm}^{-1}$ and $\left.700 \mathrm{~cm}^{-1}\right)$ functional groups. In addition, C-O and (1210$\left.1163 \mathrm{~cm}^{-1}\right)$ and $\mathrm{C}=\mathrm{O}\left(1710-1680 \mathrm{~cm}^{-1}\right)$ groups were also detected in all solvent-partitioned fractions except for ethyl acetate. $\mathrm{S}=\mathrm{O}\left(1372-1335 \mathrm{~cm}^{-1}\right.$ and $\left.1070-1030 \mathrm{~cm}^{-1}\right)$ groups were detected in chloroform, ethyl acetate, and n-butanol-partitioned fractions, while N-O (1650-1580 $\left.\mathrm{cm}^{-1}\right)$ functional group and $\mathrm{C}=\mathrm{C}\left(1678-1668 \mathrm{~cm}^{-1}\right)$ were detected in ethyl acetate-solvent partitioned fraction and n-butanol-partitioned fraction, respectively.

The FTIR analysis helps to identify a possible secondary metabolite that may be present in each fraction based on their characteristic functional groups. One of the secondary metabolites that may have exerted ACE 
Peak Table Spectrum

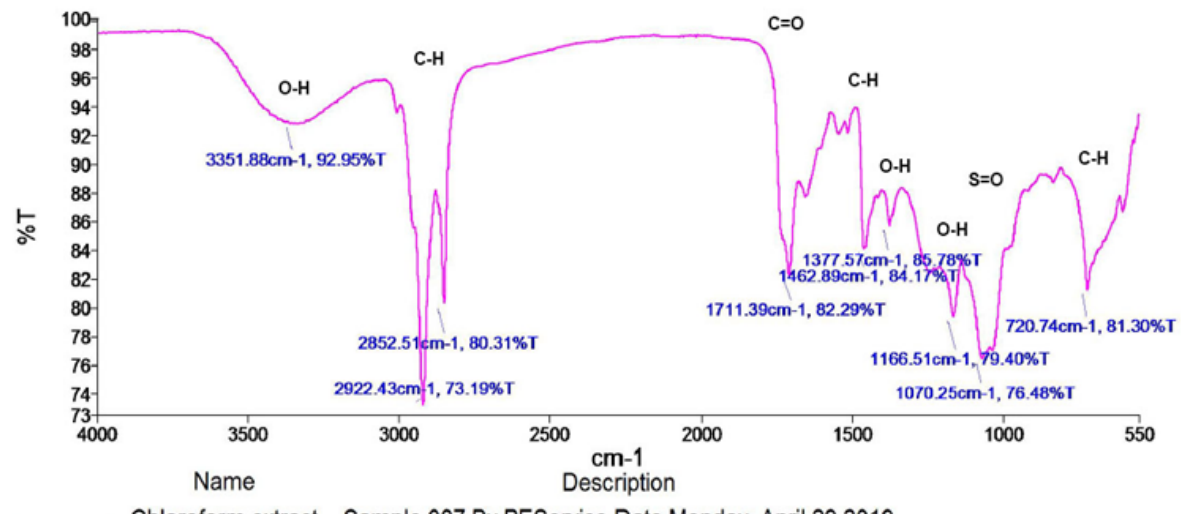

Chloroform extract Sample 007 By PEService Date Monday, April 292019

Figure 3. FTIR spectra of chloroform-partitioned fraction

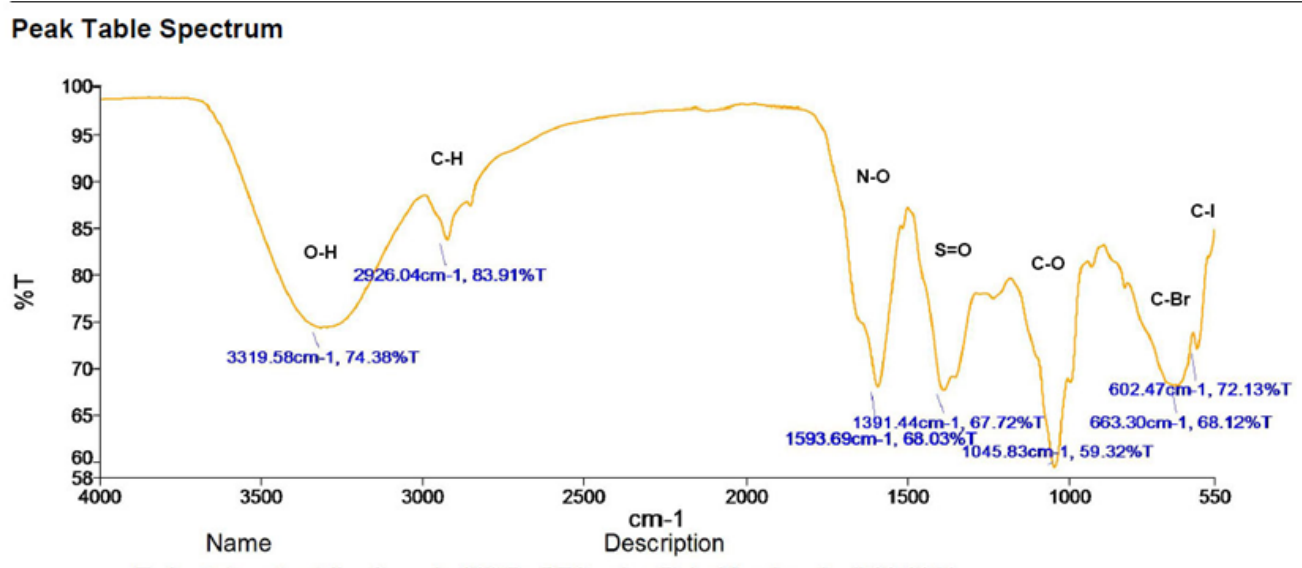

E. Acetate extract II Sample 009 By PEService Date Monday, April 292019

Figure 4. FTIR spectra of ethyl acetate-partitioned fraction

Peak Table Spectrum

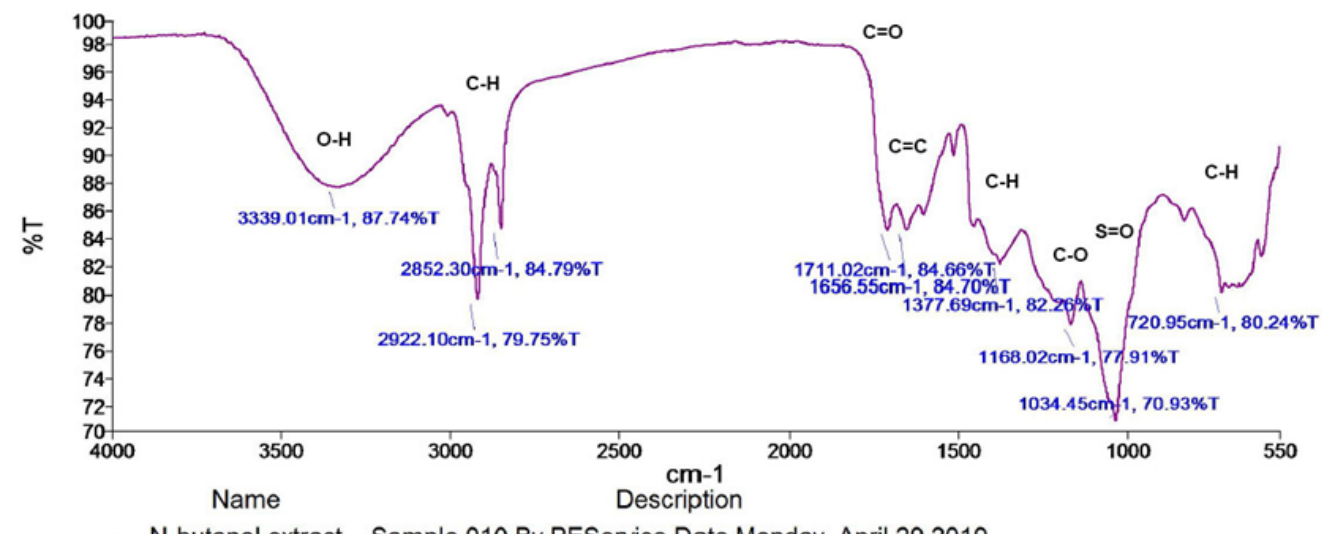

N-butanol extract Sample 010 By PEService Date Monday, April 292019

Figure 5. FTIR Spectra of n-Butanol-Partitioned Fractions

inhibitory activity would be the flavonoids. It is shown that various flavonoids can inhibit ACE with varying $\%$ inhibition, with luteolin having the highest recorded $\%$ inhibition of $95 \%$ (Garcia-vallve, et al., 2012). Furthermore, Eleusine indica is found to have two flavonoids called vitexin and isovitexin (Yeligar, 2018).
We can validate the presence of the flavonoids, since its characteristic functional groups are $\mathrm{O}-\mathrm{H}, \mathrm{C}-\mathrm{O}$, and $\mathrm{C}=\mathrm{O}$ which were revealed by the FTIR, and certain extracts of Eleusine indica contain flavonoids based on various phytochemical screening conducted in previous studies. Although flavonoids are often related to the 


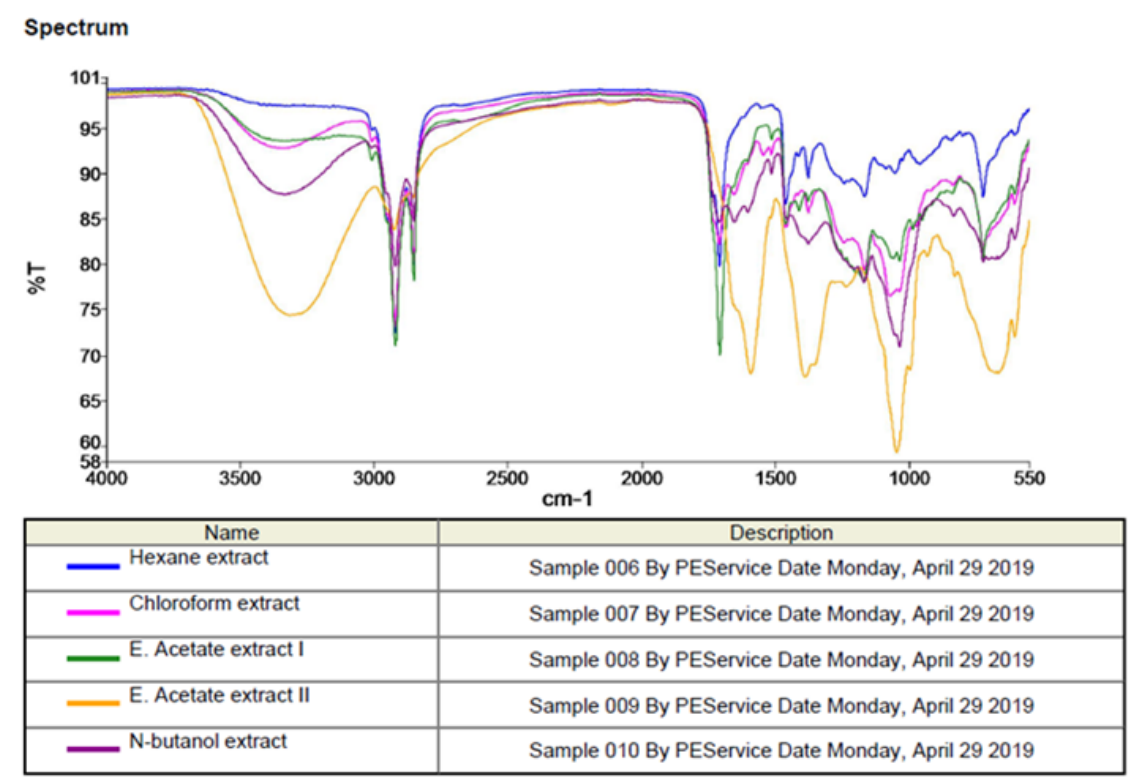

Figure 6. Overlaid FTIR spectra of the solvent-partitioned extracts of $E$. indica

anti-hypertensive effects in literatures, anti-hypertensive effects are not necessarily exclusive to it, and other secondary metabolites may also contribute or exhibit anti-hypertensive properties.

\section{ACE Inhibitory Activity}

The $\%$ inhibition of crude methanol extract (Figure 7) with varying concentrations of $500 \mathrm{ug} / \mathrm{ml}, 250 \mathrm{ug} / \mathrm{ml}$, $125 \mathrm{ug} / \mathrm{ml}$, and $62.5 \mathrm{ug} / \mathrm{ml}$ inhibits ACE at $86.919 \% \pm$ $0.006,80.108 \% \pm 0.035,59.179 \% \pm 0.023,49.346 \% \pm$ 0.048 respectively. The relationship of the $\%$ inhibition and concentration is dose dependent.

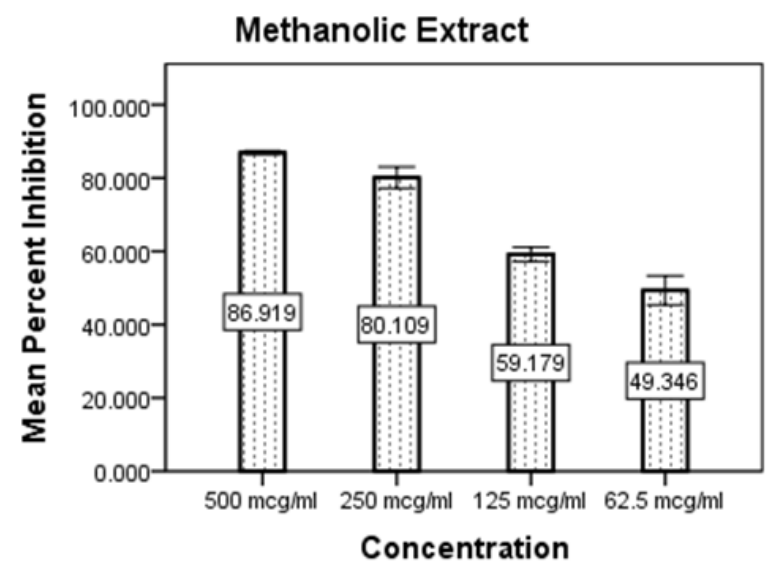

Error Bars: +/- $1 \mathrm{SE}$

Figure 7. ACE inhibitory activity of crude methanolic extract of Eleusine indica
The $\%$ inhibition of hexane-partitioned fraction (Figure 8 -A) with varying concentrations of $500 \mathrm{ug} / \mathrm{ml}, 250 \mathrm{ug} /$ $\mathrm{ml}, 125 \mathrm{ug} / \mathrm{ml}$, and $62.5 \mathrm{ug} / \mathrm{ml}$ inhibits ACE at $91.926 \%$ $\pm 0.003,74.222 \% \pm 0.032,60.352 \% \pm 0.023,35.769 \%$ \pm 0.011 , respectively. The $\%$ inhibition of chloroformpartitioned fraction (Figure 8-B) with varying concentrations are similar to the previously mentioned concentrations inhibiting $\mathrm{ACE}$ at $90.325 \% \pm 0.011$, $72.779 \% \pm 0.035,51.037 \% \pm 0.112,32.544 \% \pm 0.182$, respectively. The $\%$ inhibition of ethyl acetate-partitioned fraction (Figure 8-C) with varying concentrations are similar to the previously mentioned concentrations inhibiting ACE at $92.309 \% \pm 0.043,82.206 \% \pm 0.027$, $51.624 \% \pm 0.058,32.815 \% \pm 0.099$, respectively. The $\%$ inhibition of n-butanol-partitioned fraction (Figure 8-D) with varying concentrations are similar to the previously mentioned concentrations inhibiting ACE at 96.031\% $\pm 0.004,82.251 \% \pm 0.007,65.111 \% \pm 0.005,43.843 \%$ \pm 0.128 , respectively. All solvent fractions exhibited a dose-depended response.

All concentrations of all solvent-partitioned fractions ranging from $125-500 \mathrm{ug} / \mathrm{ml}$ have significant \% inhibition. N-butanol-partitioned fraction has the highest $\%$ inhibition across most concentrations $(500 \mathrm{ug} / \mathrm{ml}, 250$ $\mathrm{ug} / \mathrm{ml}$, and $125 \mathrm{ug} / \mathrm{ml}$ ) having a \% inhibition of $96.031 \%$, $82.251 \%$, and $65.111 \%$, respectively, with the exemption on the lowest concentration in which methanol crude extract exhibited the highest \% inhibition of $43.843 \%$. On the other hand, the chloroform-partitioned fraction has the lowest \% inhibition across all concentrations (500 $\mathrm{ug} / \mathrm{ml}, 250 \mathrm{ug} / \mathrm{ml}, 125 \mathrm{ug} / \mathrm{ml}$, and $62.5 \mathrm{ug} / \mathrm{ml}$ ) having a $\%$ inhibition of $90.325 \%, 74.779 \%, 51.037 \%, 32.544 \%$, respectively. We have observed that the polar fractions (ethyl acetate and n-butanol fractions) tend to have 


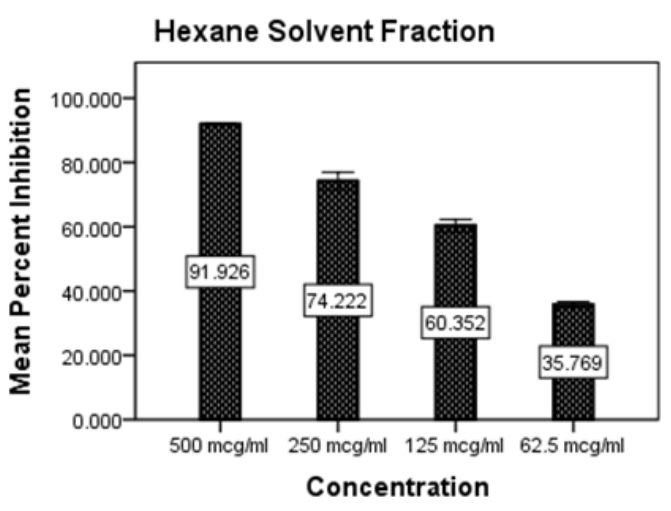

Error Bars: +/- 1 SE

(a)

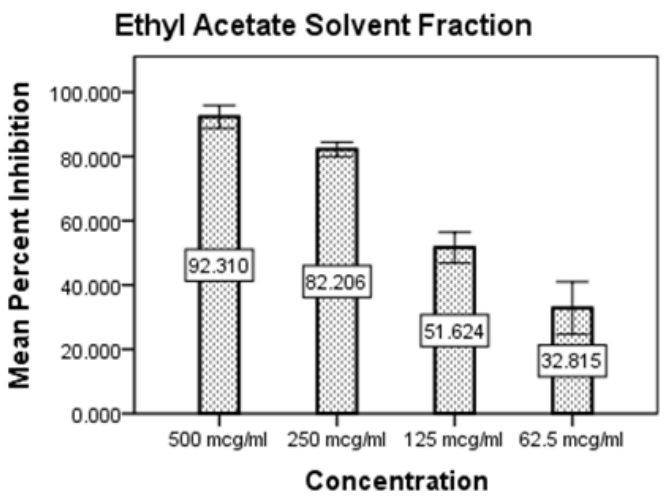

Error Bars: +/- 1 SE

(c)

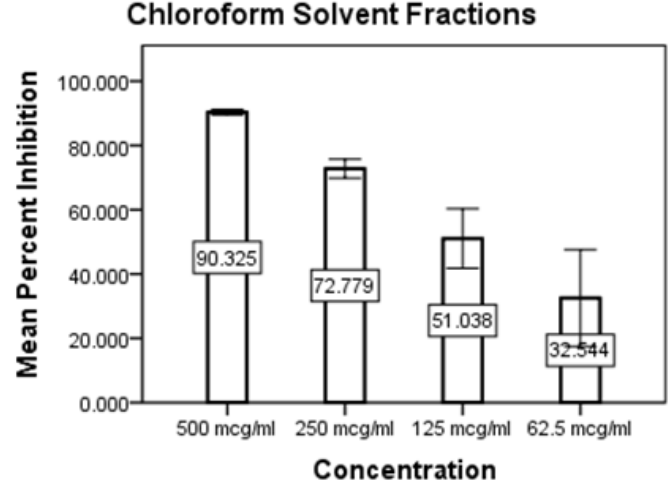

Error Bars: +/- $1 \mathrm{SE}$

(b)

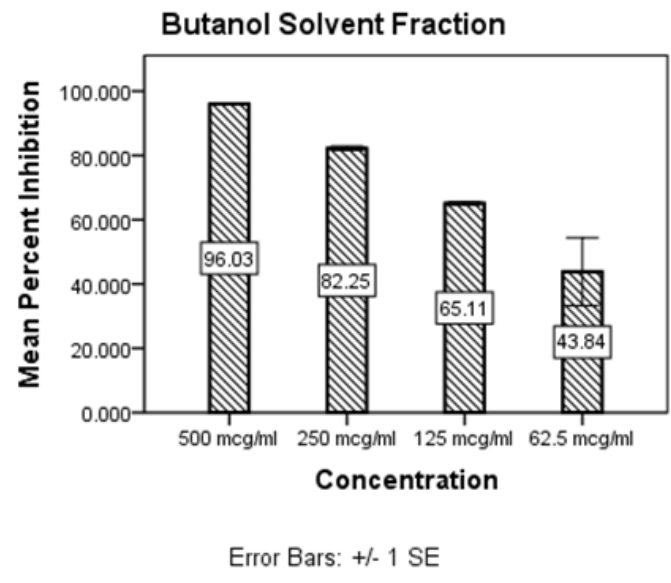

(d)

Figure 8 (a-d). ACE inhibitory activity of solvent partitioned-fractions of Eleusine indica

a higher \% inhibition (Tutor \& Chichico-Hernandez, 2017). It is possible that the secondary metabolites such as alkaloids, flavonoids, glycosides, and steroids found on ethyl acetate and n-butanol fractions may have probably contributed to its higher \% inhibition (Ajiwe, 2015 and Yeligar, 2018).

ACE Inhibitory Activity of Combined SolventPartitioned Fractions

Six combinations of the fractions ethyl acetate: hexane (EA:H), ethyl acetate:chloroform (EA:C), hexane: chloroform (H:C), ethyl acetate:-butanol (EA:B), chloroform:butanol (C:B), and hexane:n-butanol (H:B) at a concentration of $500 \mathrm{ug} / \mathrm{ml}$ were tested. Figure 9 shows the $\%$ inhibition per fraction combination. EA:H shows a $\%$ inhibition of $93.009 \% \pm 20.232$, $\mathrm{EA}: \mathrm{C}$ at $94.204 \% \pm 20.604, \mathrm{H}: \mathrm{C}$ at $89.626 \% \pm 19.577$, $\mathrm{EA}: \mathrm{B}$ at $95.737 \% \pm 20.847, \mathrm{C}: \mathrm{B}$ at $93.978 \% \pm 20.477$, and $\mathrm{H}: \mathrm{B}$ at $93.978 \% \pm 20.604$. It is observed that the combination of the polar fraction $\mathrm{EA}+\mathrm{B}$ exhibited the highest $\%$ inhibition of $95.737 \% \pm 20.847$, and that the combination of the non-polar fraction $\mathrm{H}+\mathrm{C}$ exhibited the lowest $\%$ inhibition of $89.626 \% \pm 19.577$. There might be a possible synergism present in the combined fractions, since their \% inhibition were greater than their individual effects.

$\mathrm{IC}_{50}$

Figure 10 (a-e) shows the $\mathrm{IC}_{50}$ of the methanol crude extract and each individual solvent-partitioned fraction. The $\mathrm{IC}_{50}$ of the methanol crude extract is at 164.318 $\mathrm{ug} / \mathrm{ml}$, n-butanol-partitioned fraction at $37.590 \mathrm{ug} /$ $\mathrm{ml}$, hexane-partitioned fraction at $15.357 \mathrm{ug} / \mathrm{ml}$ (the lowest), chloroform-partitioned fraction at $168.207 \mathrm{ug} /$ $\mathrm{ml}$ (the highest), and ethyl acetate-partitioned fraction at $153.078 \mathrm{ug} / \mathrm{ml}$.

Both hexane and n-butanol-partitioned fraction exhibited low $\mathrm{IC}_{50}$ compared to other portioned fractions. Both partitioned fractions have also shown some similar peaks in FTIR which refers to functional groups such as $\mathrm{C}-\mathrm{H}$, $\mathrm{C}-\mathrm{O}$, and $\mathrm{C}=\mathrm{O}$. 


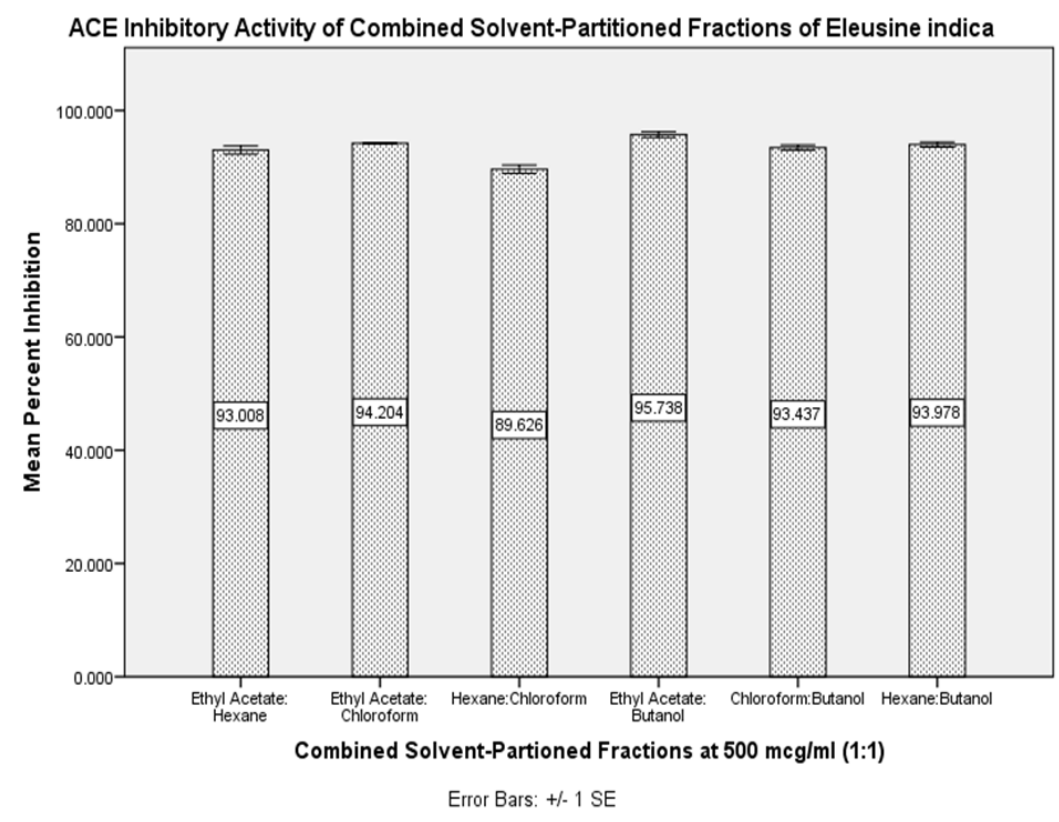

Figure 9. ACE inhibitory activity of combined solvent-partitioned fractions of Eleusine indica

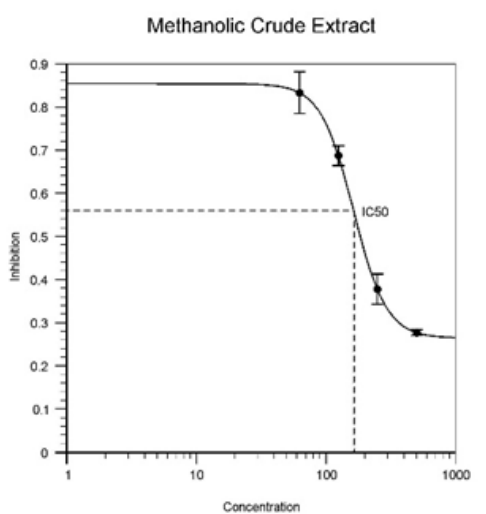

(a)

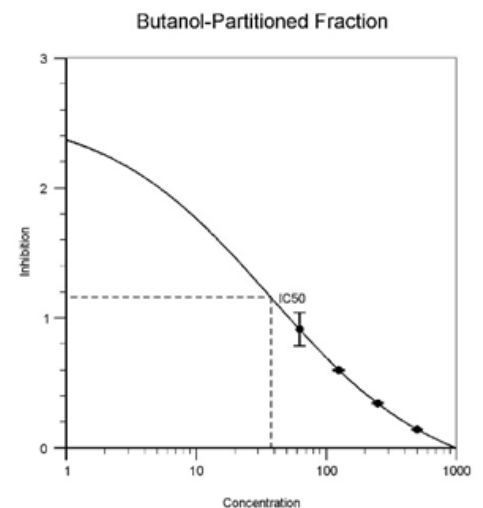

(b)

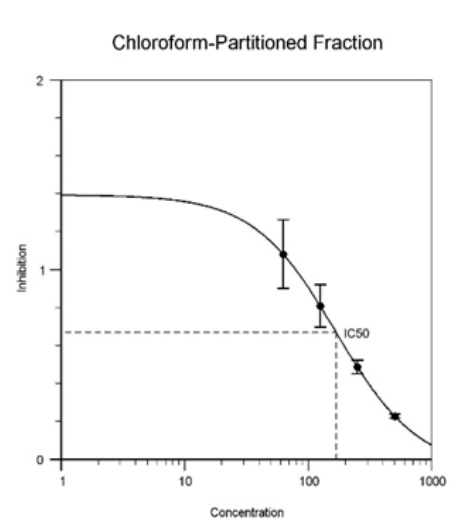

(c)

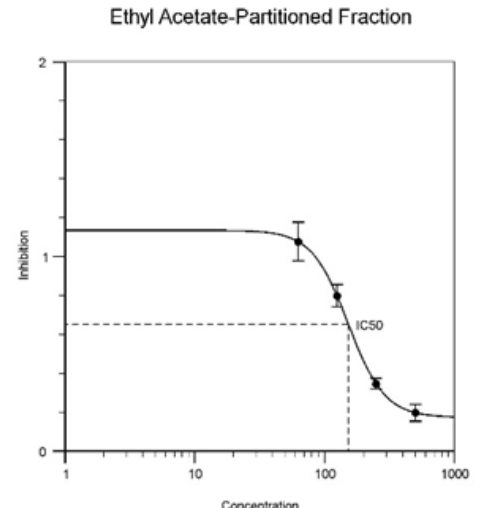

(d)

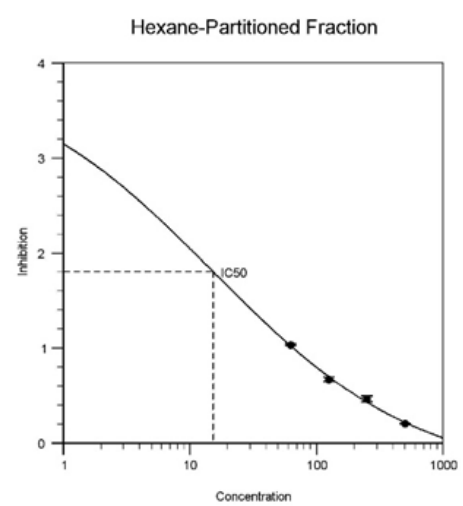

(e)

Figure 10 (a-e). IC50 methanolic crude extracts and solvent-partitioned fractions 


\section{CONCLUSIONS}

Functional group present may be associated with the antihypertensive activity of the E. indica extracts. Eleusine indica shows significant ACE inhibitory activity across all fractions at concentrations ranging from 500 $\mathrm{ug} / \mathrm{ml}$ to $125 \mathrm{ug} / \mathrm{ml}$, since $\%$ inhibition exceeds $50 \%$. Among the individual fractions, n-butanol shows the highest \% inhibition. The more polar solvent-partitioned fractions of E. indica has a higher ACE inhibitory activity compared to its less polar solvent-partitioned fractions. The higher ACE inhibitory activity may be associated with the secondary metabolites present in the more polar fractions., while among the combined fractions EA:B showed the highest \% inhibition. There is also possible synergism present in the combined solvent-partitioned fractions as their \% inhibitions are higher than their individual effects.

\section{REFERENCES}

Ajiwe, I. O. (2015). Phytochemical and anti-microbial screening of the aerial parts of Eleusine indica, 3(1), 257-264.

Babu, R. H., \& Savithramma, N. (2013). Phytochemical screening of underutilized species of Poaceae, 1(10), 947-951.

Bangalore, S., Fakheri, R., Toklu, B., \& Messerli, F. H. (2016). Diabetes mellitus as a compelling indication for use of renin angiotensin system blockers: Systematic review and meta-analysis of randomized trials. BMJ (Online), 352(December), 1-12. https://doi.org/10.1136/ bmj.i438

Barbosa-Filho, J. M., Martins, V. K. M., Rabelo, L. A., Moura, M. D., Silva, M. S., Cunha, V. L., ... Medeiros, I. A. (2006). Natural products inhibitors of the angiotensin converting enzyme (ACE). A review between 19802000. Revista Brasileira de Farmacognosia Brazilian Journal of Pharmacognosy (Vol. 16).

Cha, T. S., Najihah, M. G., Sahid, I. Bin, \& Chuah, T. S. (2014). Molecular basis for resistance to ACCaseinhibiting fluazifop in Eleusine indica from Malaysia. Pesticide Biochemistry and Physiology, 111(1), 7-13. https://doi.org/10.1016/j.pestbp.2014.04.011

Dojindo Laboratories. (2016). ACE Kit - WST Technical Manual, 29-30. Retrieved from https://www.dojindo. com/TechnicalManual/Manual_A502.pdf

Elbl G, Wagner H. A new method for the in vitro screening of inhibitors of angiotensin-converting enzyme (ACE) using the cromophore and fluorophore labelled substrate, dansyltriglycine. Planta Medica, 57(2), 137-141. https://doi.org/10.1055/s-2006-960050

Ettebong, E. O., Nwafor, P. A., \& Okokon, J. E. (2012). In vivo antiplasmodial activities of ethanolic exract and fractions of Eleucine indica. Asian Pacific Journal of Tropical Medicine, 5(9), 673-676. https://doi. org/10.1016/S1995-7645(12)60105-9

Guleria, S. (2017). Assessment of Synergy, 1-6. Retrieved from http://www.remedypublications.com/ pharmacology-and-pharmaceutics/articles/pdfs_folder/ app-v2-id1086.pdf

Hassan, S. M. (2015). Detection of hypertension among cardiac diseases inpatients at Kirkuk City Hospitals . Iraqi National Journal of Nursing Specialties (Vol. 28).

Iberahim, R., Yaacob, W. A., \& Ibrahim, N. (2015). Phytochemistry, cytotoxicity and antiviral activity of Eleusine indica (sambau). AIP Conference Proceedings, 1678(August 2016). https://doi.org/10.1063/1.4931234

Nakamura, M., Ra, J., Jee, Y., \& Kim, J. (2016). ScienceDirect Impact of different partitioned solvents on chemical composition and bioavailability of Sasa quelpaertensis Nakai leaf extract. Journal of Food and Drug Analysis, 25(2), 316-326. https://doi. org/10.1016/j.jfda.2016.08.006

Ocana, A., Amir, E., Princess, T., Hospital, M., \& Seruga, B. (2012). How valid are claims for synergy in published clinical studies?, (February). https://doi.org/10.1093/ annonc/mdr608

Quin, M., Garcia-vallve, S., \& Pujadas, G. (2012). Inhibition of angiotensin-converting enzyme activity by flavonoids : Structure-activity relationship studies, 7(11), 1-11. https://doi.org/10.1371/journal.pone.0049493

Responte, M. A., Dacar, M. R. B., Nuñeza, O. M., \& Uy, M. M. (2015). Extracts of Eleusine indica, 7(2), 90-95.

Rohman, A., \& Che, Y. B. (2012). Chemometrics and intelligent laboratory systems the chemometrics approach applied to FTIR spectral data for the analysis of rice bran oil in extra virgin olive oil. Chemometrics and Intelligent Laboratory Systems, 110(1), 129-134. https://doi.org/10.1016/j.chemolab.2011.10.010

Sharifi, N., Souri, E., Ziai, S., Amin, G., \& Amanlou, M. (2013). Discovery of new angiotensin converting enzyme (ACE) inhibitors from medicinal plants to treat hypertension using an in vitro assay. DARU Journal of Pharmaceutical Sciences, 21(1), 74. https://doi. org/10.1186/2008-2231-21-74 
Steed, S., Marble, C., Boyd, N. S., Macrae, A., \& Fnu, K. (n.d.). Biology and management of goosegrass (Eleusine indica (L.) Gaertn.) in ornamental plant production 1 other common names. Retrieved from http://edis.ifas.ufl. edu.

Tallarida, R. J. (2001). Drug synergism: its detection and applications. The Journal of Pharmacology and Experimental Therapeutics, 298(3), 865-872. https:// doi.org/10.1074/jbc.M503833200

Tallarida, R. J. (2006). An Overview of Drug Combination Analysis with Isobolograms. Journal of Pharmacology and Experimental Therapeutics, 319(1), 1-7. https://doi.org/10.1124/jpet.106.104117

Tutor, J. T., \& Chichioco-Hernandez, C. L. (2017). Angiotensin-Converting Enzyme Inhibition of Fractions from Eleusine indica Leaf Extracts. Pharmacognosy Journal, 10(1), 25-28. https://doi.org/10.5530/ pj.2018.1.5
Yeligar, V. C. (2018a). World Journal of Pharmaceutical Research in-vivo diuretic and in-vitro anti-urolithiatic, (July 2017). https://doi.org/10.20959/wjpr20178-8978

Yeligar, V. C. (2018b). World Journal of Pharmaceutical Research In-vivo diuretic and in-vitro anti-urolithiatic, (August). https://doi.org/10.20959/wjpr20178-8978

World Health Organization. (2017, May 17). Cardiovascular Diseases (CVD). Retrieved from: http://www.who.int/en/news-room/fact-sheets/detail/ cardiovascular-diseases-(cvds)

World Health Organization. (2013). WHO Traditional Medicine Strategy. Retrieved from: http://www.searo. who.int/entity/health_situation_trends/who_trm strategy_2014-2023.pdf?ua=1 